Journal of Economics, Finance and Accounting Studies (JEFAS)

ISSN: 2709-0809

DOI: 10.32996/jefas

Journal Homepage: www.al-kindipublisher.com/index.php/jefas

\title{
The Effects of Punctuality, Quality of Financial Statements, And The Effectiveness of Financial Statement Information on The Improvement of Company Financial Statement Performance
}

\author{
Bahrum Naz Sitepu ${ }^{1} \square$ Endang Kurniati ${ }^{2}$, Mardiah Hasanah Nasution ${ }^{3}$ and Rahmad Dani ${ }^{4}$ \\ ${ }^{1234}$ Department of Accounting, Akademi Akuntansi YPK Medan, Indonesia
}

$\square$ Corresponding Author: Bahrum Naz Sitepu, E-mail: sitepubahrumnaz@gmail.com

\begin{abstract}
ARTICLE INFORMATION
Received: 08 September 2021

Accepted: 04 October 2021

Published: 23 October 2021

DOI: 10.32996/jefas.2021.3.2.11

\section{KEYWORDS}

Punctuality, financial statements, statement company financial performance.

\section{ABSTRACT}

Companies require a short time in creating their financial statements reporting their financial conditions to the public, stakeholders, and investors. In 2019-2020, 80 companies did not publish their financial statements. This phenomenon affected the effectiveness and the financial statement performance and the overall company performance. As a result, the financial statement performance was not good, and the number of investors' trusts in responding to the financial statements of 80 issuers in the stock market decreased. The declining investors' trust was caused by the low effectiveness and quality of the financial statements of 80 companies listed on the IDX. Therefore, the IDX demanded the 80 issuers repair their financial statements based on the actual conditions. This research employed a descriptive quantitative method through multiple linear regression analysis using SPSS 20 . The population of this study involved 100 users of financial statements in several Indonesian companies. Meanwhile, the samples of 100 users were taken using the census method distributing a questionnaire directly to the samples via email. Based on the partial and simultaneous hypothesis tests, the data analysis results showed that the punctuality, the quality of financial statements, and the effectiveness of the financial statement information had a positive and significant effect on the companies' financial statement performance.
\end{abstract}

\section{Introduction}

As a business unit, a company functions to increase production and assist the government in creating efficient products and increasing GDP. The success of these roles can always be measured through the financial condition as outlined in the financial statements. Financial statements guarantee transparency and openness of a company to show that the financial statements are prepared and reported to various parties, especially external and internal parties. This assurance aims to increase the various parties' trust that the companies are in good condition. Lawscheski and Nasev (2021), the openness and transparency of a company's financial statements are intended for the involved parties, including external parties, such as the government and investors. These external parties determine whether the company is in good condition or not. Transparent and accountable financial statements guarantee the company's desire to improve its quality in terms of the company's ability to generate profits and have a good balance sheet based on investors', customers', and other stakeholders' perspectives. This assurance indicates that the company always strives to be capable and have integrity in running its business. Companies require a short time in preparing financial statements reporting their financial conditions to the public, stakeholders, and investors. However, some companies lately reported their financial statements indicating bad quality existing guidelines. Hence, the reported financial statements were ineffective and caused unwell performance of the financial statements thus affecting the company's overall performance. Several companies were not punctual in reporting their financial statements in 2019-2020. Some of these companies have been listed or existed on the Indonesian stock market (Indonesian Stock Exchange), while 80 companies did not submit their financial statements on time (Gumilar, 2020). The delay in financial reporting has impacted the performance of the companies' financial statements and overall performance. As a result, the performance of the financial statements was not good, and the number of investors'

Copyright: (c) 2021 the Author(s). This article is an open access article distributed under the terms and conditions of the Creative Commons Attribution (CC-BY) 4.0 license (https://creativecommons.org/licenses/by/4.0/). Published by Al-Kindi Centre for Research and Development, London, United Kingdom. 
trusts in responding to the financial reporting of 80 issuers in the stock market decreased. The declining trust from the investors was caused by the low effectiveness and quality of the financial statements of 80 companies listed on the IDX. Therefore, the IDX demanded the 80 issuers repair their financial statements based on the actual conditions. Novolya et al. (2016), the effectiveness of financial statement information is shown by high quality, the use of efficient resources, actual situation, and the existing reports very useful for the interests of various parties in making decisions to future operational interests of the company. Tran et al. (2021), quality financial statements are financial reports easily understood by stakeholders for decision making. The reports are timely, relevant, and useable for decision-making, and the information is reliable for decision-making. Meanwhile, the reliability of financial statements lies in real and ongoing conditions at that time. Therefore, such a report is useful for various company stakeholders in making all decisions related to company operations. Therefore, these 80 issuers should always improve the quality of their financial statements and report them punctually so that the information submitted is reliable, has good effectiveness, and is useful for decision making. If the companies meet those requirements, decisions made regarding the companies' operations will be proper and not harm the companies due to misinformation.

\section{Literature Review}

\subsection{Punctuality}

Astuti and Surtikanti (2020), punctuality preparing financial statements is a process carried out in issuing credible financial statements following a predetermined time, namely one year. Diana and Setiawati (2017) state that the punctuality in making financial statements shows that the financial statements prepared must be in accordance with the time set based on the applicable rules in Accounting and a country. The financial statements published timely will show the effective and good performance of the companies so that the financial information is useable by various parties in decision making.

\subsection{Quality of Financial Statements}

According to Hakim and Rosini (2015), the quality of financial statements is the ability of the financial statements to provide accurate, credible, and accountable information, following the applicable rules and procedures, where the financial statements made can be useful for decision making. Hans, et al. (2014) state that quality financial statements are financial reports that are multi-purpose and can improve the quality of the company so that the reports can show the existing conditions and meet the company's stakeholders' expectations.

\subsection{The Effectiveness of Financial Statement Information}

Mulyadi (2016) argues that the effectiveness of financial statement information is part of the effectiveness of accounting information systems that can be used properly to provide an overview of the financial statement ability to provide accurate, credible, and valid information for various parties in the context of making decisions and improving strategies. Kartikahadi (2018) points out that the financial statement information is effective if the financial statements have been prepared based on accounting standards, reported on time, and the report can help companies increase productivity and improve performance.

\subsection{Financial Statement Performance}

Winarso and Nuryani (2020) state that the financial statement performance is the ability of the financial statements to help companies improve their performance, where the companies' performance can be seen from a positive balance sheet report and maximum profit is obtained from the company operational activities. Zamzami and Nusa (2017) point out that the performance of financial statements can be viewed from the ability of financial statements to provide valid and accurate reports and can help companies achieve the goals that have been set.

\section{Research Method}

This research employed a quantitative descriptive research method. Sugiarto (2017) states that the quantitative research method explains the relationship between several variables by deeply investigating the existing problems, and then describing as well as examining the relationship between the variables. The population of this study involved 100 users of financial statements in several Indonesian companies. The samples of this research were taken by using the census.

\section{Results and Discussion}


4.1 The Effects of Punctuality, Quality of Financial Statements, and the Effectiveness of Financial Statement Information on the Financial Statement Performance

Analysis of Multiple Linear Regression Equation

Table 1 Multiple Linear Regression Equation

Coefficients

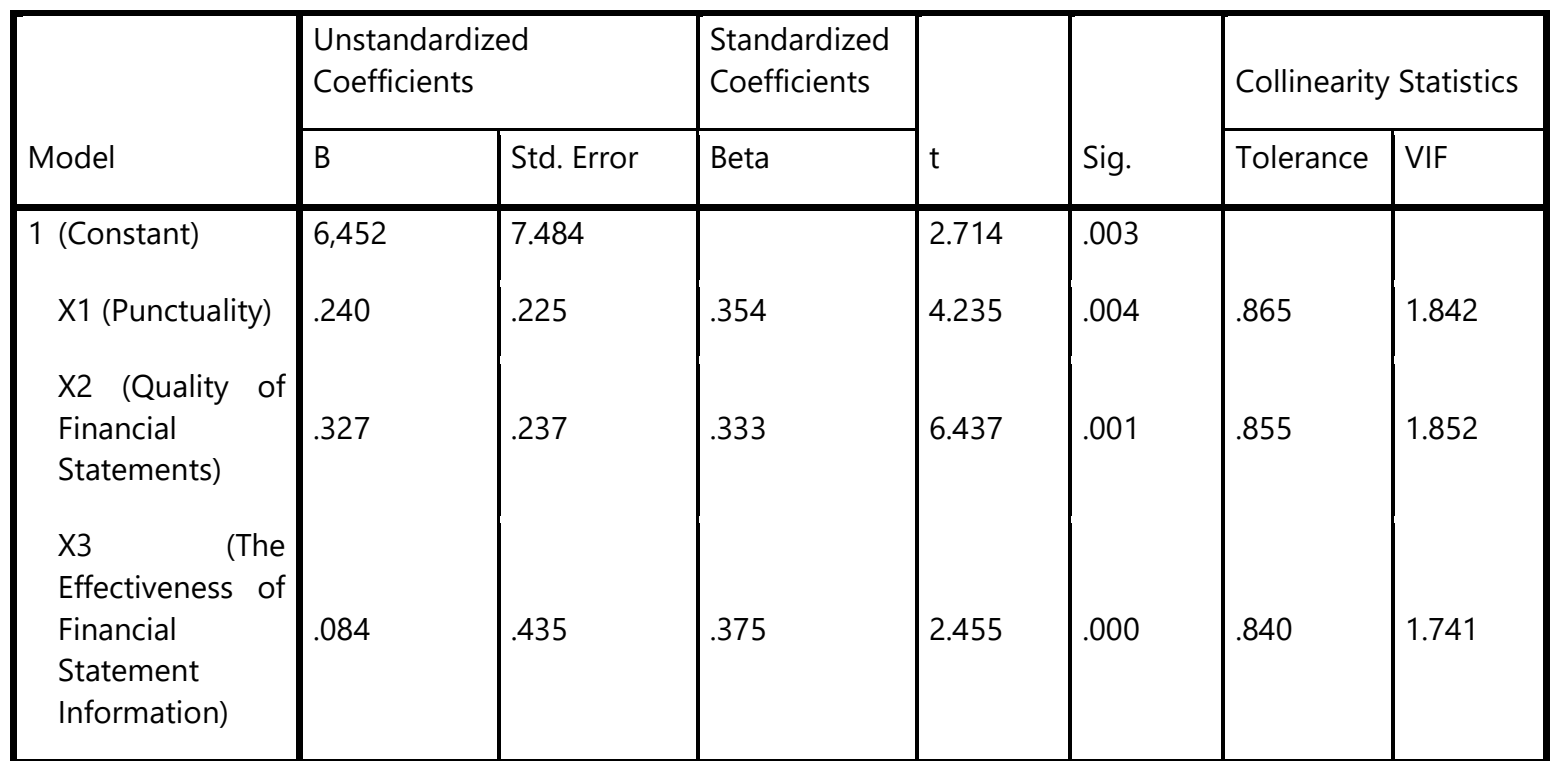

a. Dependent Variable: $Y$

Source: Data Processing (SPSS), 2020

Table 1 presents that the linear regression equation is as follow:

$$
Y=6.452+0.240 X_{1}+0.327 X_{2}+0.084 X_{3}
$$

The value of the regression coefficient X1 for punctuality is 0.240 . It indicated that punctuality had a positive effect on the financial statement performance, where the more punctual the company's financial statements made, the financial statement performance increased by $0.240 \%$. The value of the regression coefficient $\mathrm{X} 2$ for the quality of the financial statement is 0.327 . It showed that the quality of financial statements positively and significantly affected the financial statement performance, where the increase in the quality of the financial statements made by the company enhanced the financial statement performance by $0.327 \%$. The value of the regression coefficient $X 3$ for the effectiveness of the financial statement information is 0.084 . It revealed that the effectiveness of the financial statement information had a positive and significant impact on the financial statement performance, where the more effective the financial statements presented by the company, improved the financial statement performance by $0.084 \%$.

\subsection{Determination Coefficient $\left(R^{2}\right)$}

Table 2 Results of Determination Coefficient Test Determinasi

\begin{tabular}{|c|c|c|c|c|c|c|c|c|c|c|}
\hline \multirow[b]{3}{*}{ Mode } & \multicolumn{9}{|c|}{ Model Summary } & \multirow[b]{3}{*}{$\begin{array}{l}\text { Durbin- } \\
\text { Watson }\end{array}$} \\
\hline & \multirow[b]{2}{*}{$\mathrm{R}$} & \multirow[b]{2}{*}{$\begin{array}{l}\text { R } \\
\text { Square }\end{array}$} & \multirow[b]{2}{*}{$\begin{array}{l}\text { Adjusted } \\
\text { R Square }\end{array}$} & \multirow[b]{2}{*}{$\begin{array}{l}\text { Std. Error } \\
\text { of the } \\
\text { Estimate }\end{array}$} & \multicolumn{5}{|c|}{ Change Statistics } & \\
\hline & & & & & \begin{tabular}{|l|}
$\mathrm{R}$ Square \\
Change
\end{tabular} & $\begin{array}{l}\mathrm{F} \\
\text { Change }\end{array}$ & df1 & $\mathrm{df} 2$ & $\begin{array}{ll}\text { Sig. } & F \\
\text { Change } & \end{array}$ & \\
\hline 1 & $.748^{a}$ & .768 & .832 & 4.4325 & .768 & 7.428 & 3 & 96 & .000 & 2.125 \\
\hline
\end{tabular}

a. Predictors: (Constant), X4, X2, X3, X1

b. Dependent Variable: $Y$

Source: Data Processing (SPSS), 2020 
Table 2 presents the determination coefficient (Adjusted R Square) value is 0.832 . In other words, $83.2 \%$ of punctuality, the quality of financial statements, and the effectiveness of financial statement information very strongly influenced the financial statement performance, while the remaining $16.8 \%$ were affected by other variables not discussed in this study.

\subsection{Simultaneous Hypothesis Test}

Table 3 Results of Simultaneous Test

ANOVA

\begin{tabular}{|ll|l|l|l|l|l|}
\hline \multicolumn{2}{|l|}{ Model } & Sum of Squares & $\mathrm{df}$ & Mean Square & $\mathrm{F}$ & Sig. \\
\hline 1 & Regression & 37.320 & 3 & 6.210 & 8.725 & $.000^{\mathrm{b}}$ \\
& Residual & 2554.05 & 96 & 4.654 & & \\
& Total & 2435.02 & 99 & & & \\
\hline
\end{tabular}

a. Dependent Variable: $Y$

b. Predictors: (Constant), X4, X2, X3, X1

Source: Data Processing (SPSS), 2020

Table 3 presents the F-table value is 8.725 higher than the F-count value of 2.70 . This result indicated that punctuality, the quality of financial statements, and the effectiveness of the financial statement information had a positive and significant effect on financial statement performance. Partial Hypothesis Test

Table 4 Results of Partial Test

\section{Coefficients}

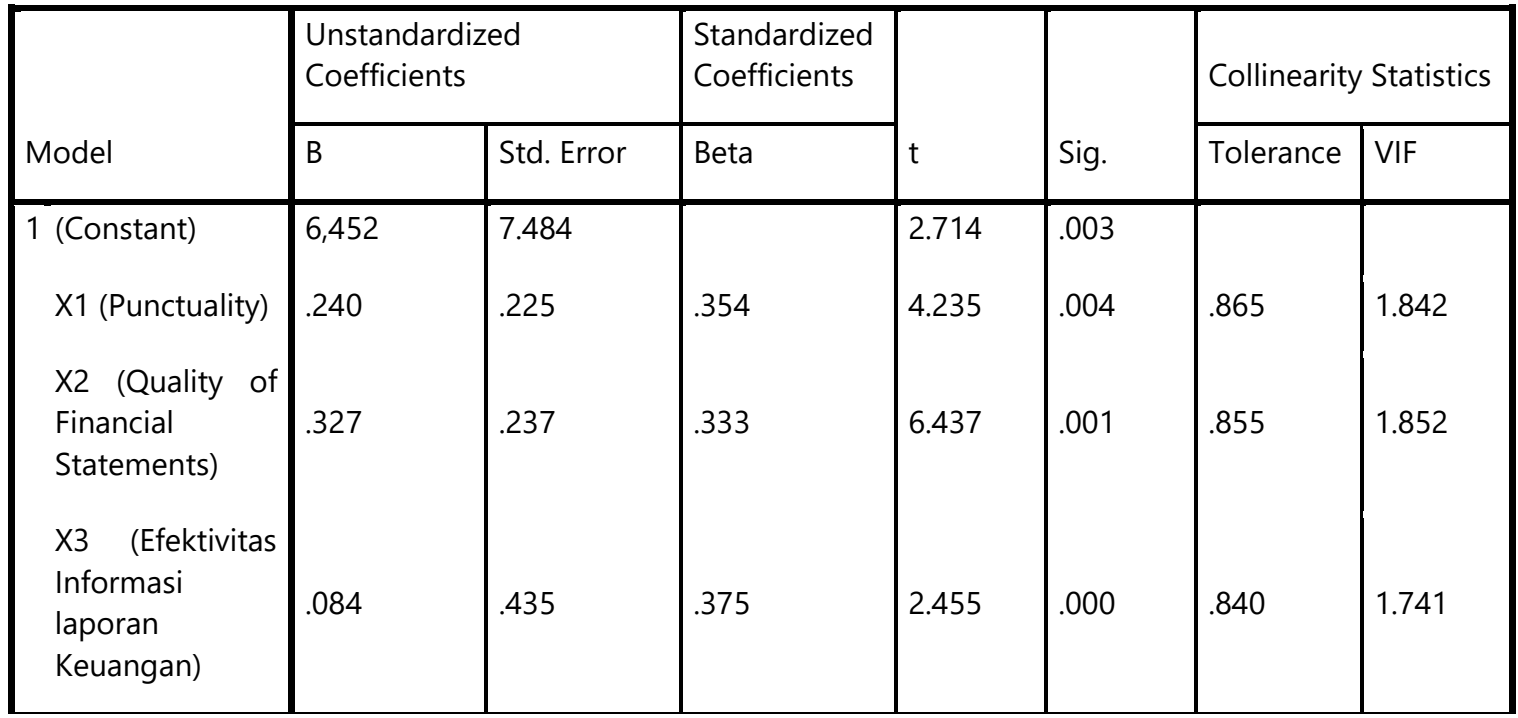

a. Dependent Variable: $Y$

Source: Data Processing (SPSS), 2020

Based on Table 4, punctuality, the quality of financial statements, and the effectiveness of financial statement information positively and significantly affected the financial statement performance. This result was proven by the $t$-value of these three variables greater than the t-table value of 1.661 .

\section{Conclusion}

Based on the research analysis, the researcher concluded the results as followed: Punctuality had a positive and significant effect on the financial statement performance. The quality of financial statements positively and significantly affected financial statement performance. The effectiveness of the financial statement information had a positive and significant impact on the financial 
statement performance. Punctuality, the quality of financial statements, and the effectiveness of the financial statement information positively and significantly influenced the financial statement performance

\section{References}

[1] Astuti, W., A. and Surtikanti K. (2020), Financial Accounting, Jakarta: Science Engineering Publisher

[2] Brata, T. Y. (2021). THE EFFECT OF A SITUATIONAL LEADERSHIP STYLE AND THE APPLICATION OF ACCOUNTING INFORMATION SYSTEMS TO FRAUD ON VILLAGE FUND MANAGEMENT IN TANGERANG DISTRICT. Dinasti International Journal of Digital Business Management, 2(5), 838-843.

[3] Dewi, L., Santoso, E. B., Laturette, K., \& Pranatasari, F. D. (2019). Father's Active Role as a Determinant of Successful Family Business in the Next Generation (Case Study in Water Sport Family Business Indonesia).

[4] Laschewski, C., \& Nasev, J. (2021). Limits of private firms' disclosure avoidance-Evidence from enforcing financial statements publication in Germany. Journal of Accounting and Public Policy, 106872.

[5] Kristina, T., \& Sugiarto, C. (2020). The role of trust mediates in the influence of social media marketing and Electronic Word-of-Mouth on purchase intention. Management and Entrepreneurship: Trends of Development, 4(14), 102-113.

[6] Maharani, A. M., \& Sulistyowati, R. (2020). Analisis Pengaruh Budaya Organisasi Terhadap Penerapan Sistem Pengendalian Internal Dan Implikasinya Pada Integritas Ukm Di Bojonegoro. Substansi: Sumber Artikel Akuntansi Auditing dan Keuangan Vokasi, 4(2), 157-172.

[7] Nurfitriana, A. (2018) RELATION BETWEEN IFRS CONVERGENCY, COMPANY CHARACTERISTICS, AUDITOR QUALITY AND TIMELINESS OF FINANCIAL REPORTING EVIDENCE FROM INDONESIA.

[8] Rahman Hakim, D., \& Rosini, I. (2018). Akuntansi Keuangan 1.

[9] Srimindarti, C, (2008), Timeliness of Financial Reporting, Journal of Economic Focus (FE), Vol. 7, No. 1, ISSN: 1412-3851, p. 14-21

[10] Sopanah, A., Fatoni, I., Danawanti, M. O., \& Harmadji, D. E. (2020). BUNGA RAMPAI AKUNTANSI PUBLIK: ISU KONTEMPORER AKUNTANSI PUBLIK. SCOPINDO MEDIA PUSTAKA.

[11] Tran, Y. T., Nguyen, N. P., \& Hoang, T. C. (2021). The role of accountability in determining the relationship between financial reporting quality and the performance of public organizations: Evidence from Vietnam. Journal of Accounting and Public Policy, 40(1), 106801.

[12] Winarso, E \& Nuryani, N. (2020), Advanced Financial Accounting Based on the Latest IFRS and SAK, Book 1, Bogor: Bypass Press publisher 